\title{
Methods of overcoming dormancy in seeds and initial development of Black Wattle
}

\author{
Ricardo Alberti', Fernanda Lais Novello", Eduardo Alexandre Albarello"', \\ Ewerton Jose de Medeiros Torres ${ }^{\mathrm{IV}}$,Fernando de Jesus Moreira Junior ${ }^{\mathrm{V}}$
}

\begin{abstract}
The objective of this work was to analyze the efficacy of different methods of dormancy break in seeds of Acacia mearnsii De Wild. The work was performed at the UFSM Botany Lab and Forest Nursery, in Frederico Westphalen, RS. The treatments were: (T1) control; (T2) immersion in hot water $\left(90^{\circ} \mathrm{C}\right)$ for 5 minutes, followed by rest; (T3) immersion in hot water $\left(90^{\circ} \mathrm{C}\right)$ for 10 minutes, followed by rest; (T4) chemical scarification with concentrated sulfuric acid for 3 minutes, followed by washing under running water; (T5) chiseling with concentrated sulfuric acid for 5 minutes, followed by washing under running water. The seeds were sown in plastic trays with Oxisol and vermiculite. The results were submitted to analysis of variance and data were differentiated by Test $t$ with $5 \%$ of probability. The most efficient treatment to overcome dormancy was T2, presenting $81.29 \%$ of germinated seeds and IVG of 18.23 days for germination. This treatment was also the best for the variables of physical vigor and best performing root length and aerial part, and did not differ from improved treatments for diameter and green mass weight.
\end{abstract}

Keywords: Acacia mearnsii; Forest seeds; Germination; Seed dormancy; Scarification; Physical vigor.

\footnotetext{
' Universidade Federal de Santa Maria, Santa Maria, Brasil. E-mail: r-alberti@live.com.

" Universidade Federal de Santa Maria, Santa Maria, Brasil. E-mail: fernanda.novello@yahoo.com.br.

III Universidade Federal de Santa Maria, Santa Maria, Brasil. E-mail: edu_albarello@hotmail.com.

IV Universidade Federal de Santa Maria, Santa Maria, Brasil. E-mail: ewerton@agronomo.eng.br.

$\checkmark$ Universidade Federal de Santa Maria, Santa Maria, Brasil. E-mail: fmjunior777@yahoo.com.br.
} 


\section{INTRODUCTION}

Acacia mearnsii De Wild, popularly known as Black Wattle, belongs to the Fabaceae family and Mimosoideae subfamily, and originates from Australia's SouthEastern, being a tree of great economic and ornamental importance (SCHUMACHER et al., 2003). The species was introduced in Brazil in 1918 and in 2018 ranks first among the most planted forest species in the country (IBÁ, 2018).

The economic role that the Black Wattle plays is closely related to the production of tannin and wood, which is used as firewood and coal, also serving as a raw material product for paper, cellulose and offset industries. In addition, it is evident its important ecological role in soil conservation and recovery (EMBRAPA, 1992). The benefits offered by this species are emphasized by its rapid growth, especially in the southern region of Brazil, where the pant finds optimal soil and climatic conditions for development (OLIVEIRA, 2007).

However, like most leguminous, the seeds have hard teguments that are impermeable to water and gases, making uniform establishment in the field difficult (BERTALOT; NAKAGAWA, 1998). According to BEWLEY and BLACK (1994), dormancy can manifest itself in three ways: dormancy imposed by the integument, embryonic dormancy and dormancy due to imbalance between promotor substances and inhibitors of germination. For Yap and Wong (1983), in Black Wattle this germination impediment can occur due to impermeability of the tegument to the water.

In view of this, methods proposed by Sacco (1974) to overcome this type of dormancy are based on dissolving this waxy cuticular layer or promoting striations in the seed coat. Mayer and Poljakoff-Mayber (1989) further add that this impermeability can be overcome by any treatment that results in the tearing or weakening of the integument allowing the passage of water and gas Exchange, initiating the germination process.

Among the methods used successfully to overcome the dormancy of species of the Leguminosae family are the chemical scarification (BIANCHETTI and RAMOS, 1981a; NICOLOSO et al., 1997; BIANCHETTI and RAMOS, 1981c; SILVA and SILVA, 1993) and mechanical scarification (BIANCHETTI and RAMOS, 1981b), as well as immersion in hot 
water (BIANCHETTI and RAMOS, 1981b; RECH et al., 1980; BIANCHETTI and RAMOS, 1982; SILVA and SILVA, 1993). The application and efficiency of these treatments depends on the dormancy intensity, which varies considerably between species, provenances and years of seed collection.

The immersion of the seeds in hot water has been used to promote the germination of Acacia mangium (SILVA and SILVA, 1993; LIMA and GARCIA, 1996), Acacia senegal (TORRES and SANTOS, 1994) and Acacia mearnsii (RECH et al., 1980; BIANCHETTI and RAMOS, 1982).

According to Bianchetti and Ramos (1982), immersion of the seeds in hot water at $90^{\circ} \mathrm{C}$ followed by rest in the same water, outside the heating for 24 hours, was the most recommended treatment for the production of Black Wattle seedlings.

Results obtained by Lima and Garcia (1996) for seeds of A. mangium submitted to immersion in water at $80{ }^{\circ} \mathrm{C}$ until reaching room temperature (2 hours), was the treatment that provided greater length of the seedlings. Already, for Alves et al. (2000), seeking to overcome Bauhinia mondranta dormancy, with the immersion in water at 85 ${ }^{\circ} \mathrm{C}$ the death of all the seeds occurred, and in B. ungulata seeds, a low percentage of germination (6\%).

Alves et al. (2000), suggest immersion in concentrated sulfuric acid $\left(\mathrm{H}_{2} \mathrm{SO}_{4}\right)$, immersion in boiling water or scarification, as a treatment to overcome dormancy. The effectiveness of sulfuric acid was found by several authors: Frank and Baseggio (1998) in Desmodium inacanum DC and Lathynus nervores Lam; Bertalot and Nakagawa (1998) in Leucaena diversifolia.

According to Garcia and Cícero (1992), the use of $\mathrm{H}_{2} \mathrm{SO}_{4}$ in overcoming seed dormancy presents contradictory results, which can either favor or impair seed germination. This statement was verified by Goedert (1985) when studied the use of $\mathrm{H}_{2} \mathrm{PO}_{4}$ in overcoming seed dormancy of Brachiaria humidicola and $B$. decumbens. The author found that this treatment reduced the germination of $B$. humidicola seeds, however, the same treatment promoted a $50 \%$ increase in germination of $B$. decumbens seeds when compared to the control, although, apparently, has damaged part of the seeds. 
According to Albrecht (1981), the exposure time to sulfuric acid is directly related to the hardness of the integument and, furthermore, after immersion the seeds must be washed in running water for 10 minutes to remove the residues. Barazetti and Sccoti (2010) stated that concentrated sulfuric acid for 4 minutes was the best treatment to evaluate the viability of Mimosa scabrella seeds, whereas, for Bianchetti and Ramos (1982), scarification with commercial sulfuric acid concentrated for 15 minutes was not efficient to overcome dormancy of Black Wattle.

The dendrometric variables evaluated as seedling length, stem diameter and green weight are important, because according to Silva et al. (2007) studies have reported that plant growth efficiency may be related to the ability of seedlings to adapt to ambient sunlight conditions.

The mechanism of seed dormancy, presented by most forest species, generates the necessity for studies that better explain this process. According to Roversi et al. (2002), it is necessary to test with practical methods of overcoming dormancy of Black Wattle, aiming at a significant improvement in germination and also in the performance of seedlings in the seedling nursery, accelerating and standardizing the establishment of plants in the field.

In view of the foregoing, the objective of this work was to evaluate the effect of different treatments on the dormancy overcoming of Acacia mearnsii De Wild. seeds, which may provide high percentages of germination and that may be applicable to laboratory tests and seedling nursery conditions.

\section{MATERIALS AND METHODS}

The seeds of Acacia mearnsii were purchased from the company MP Sementes, located in the county of ljuí, Rio Grande do Sul. The work was carried out in the Botany Laboratory and in the Forest Nursery of the Federal University of Santa Maria (UFSM), campus Frederico Westphalen. In the laboratory, the first step was to separate the seeds according to their size, those smaller than $2.0 \mathrm{~mm}$ were eliminated. The selected seeds were submitted to these treatments to overcome dormancy: (T1) Witness (without intervention); (T2) Immersion in hot water $\left(90^{\circ} \mathrm{C}\right.$ ) for 5 minutes, followed by 
standing in water at room temperature for 16 hours; (T3) Immersion in hot water (90 ${ }^{\circ} \mathrm{C}$ ) for 10 minutes, followed by standing in water at room temperature for 16 hours; (T4) scarification with concentrated sulfuric acid for 3 minutes, followed by washing in running water for 10 minutes; and (T5) chemical scarification with concentrated sulfuric acid for 5 minutes, followed by washing in running water for 10 minutes. In the treatments with sulfuric acid the seeds were placed in Becker cups and immersed in enough acid to cover them.

The second stage was carried out in the Forest Nursery, with individual sowing in trays with polyethylene tubes containing 6 grooves with a capacity of $110 \mathrm{~cm}^{3}$, on 21 th November, 2016. As substratum, three pieces of clayey soil of the type Red Latosol (EMBRAPA, 1999) sifted and one of vermiculite of fine texture were used. Each treatment consisted of 96 seeds, being made 2 replicates of 48 , totaling 5 trays of 96 tubes each.

After sowing the trays were conditioned in an greenhouse in the Florest Nursery, equipped with a sprinkler irrigation system. The irrigation is automated four times a day, lasting ten minutes at a time. The greenhouse used has a measurement of $120 \mathrm{~m}^{2}$ (10 $\mathrm{m}$ wide $\times 12 \mathrm{~m}$ long), covered with plastic film in the form of an arc.

From the emergence of the first seedling were counted, every two days, the germination. This procedure was carried out until the 30th day after sowing and on this date the final count of the germination test was done, being evaluated the percentage of germination (BRASIL, 1992) and the rate of germination (IVG) (MAGUIRE, 1962). IVG was determined by the sum of the number of normal seedlings germinated each day, divided by the number of days elapsed between sowing and emergence, according to the formula (Maguire, 1962):

$$
I V G=\frac{G_{1}}{N_{1}}+\frac{G_{2}}{N_{2}}+\ldots+\frac{G_{n}}{N_{n}}
$$

on what:

$G_{1}, G_{2}, G_{n}=$ number of seedlings in the first, second and last counts.

$N_{1}, N_{2}, N_{n}=$ number of days of sowing at the first, second and last count. 
The final evaluation of the variables root length, aerial part length, stem diameter and green mass weight was made 60 days after sowing. The seedlings were carefully removed from the tubes, washed and placed in bags numbered with the treatment and the repetition to which they belonged. After this process, they were taken to the Botany Laboratory and deposited on filter paper to remove excess water. To measure the length of the primary root and aerial part was used a ruler millimeter and to measure the diameter of the stem was made use of a pachymeter. Data were expressed in millimeters. After that, the seedlings were weighed in a precision scale to obtain the green mass. These data were expressed in grams.

The results were analyzed according to the completely randomized design and the treatments were compared by the $t$ test at the $5 \%$ probability level. The statistical analysis of the data was performed by the software Assistat (SILVA and AZEVEDO, 2002).

\section{RESULTS AND DISCUSSION}

From the seventh day after sowing the first germinated seeds were observed, and the first count was made. The treatments T2, T3, T4 and T5 presented respectively: $3,5,1$ and 2 germinated seeds. The witness, however, had its first germination on the 9th day, with 2 emergencies. As shown in Figure 1, treatments T2 and T3 had higher germination expression. This happened during the second week of evaluation, with 36 and 37 seeds germinated, respectively. Already, for T1 and methods of immersion in $\mathrm{H}_{2} \mathrm{SO}_{4}$ for 3 and 5 minutes, less germination occurred and no week was highlighted, remaining almost constant.

Table 1 shows the results obtained at the end of the 30 days of evaluation, where it was found that the treatments that used water as a scarifier (T2 and T3) in both immersion times promoted greater final germination of the seeds when compared to other methods tested. For the treatments evaluated, there were significant statistical differences for the germination variable, so that in $\mathrm{T} 1$ the percentage of germination was $9.37 \%$ being characterized as the worst treatment observed. The T2, with $81.29 \%$, promoted the highest percentage of germination and was characterized as the best treatment for the overcoming of dormancy in Black Wattle seeds. However, T3 
presented $81.25 \%$ and did not differ statistically from $\mathrm{T} 2$, and could also be considered as the best treatment. The percentages of germination for T4 and T5 were lower. With $14.58 \%$ and $13.54 \%$, respectively, these treatments differed statistically from the best, but outweighed the witness treatment. The seeds treated chemically took the same time to initiate the germination when compared to the treatments with immersion in hot water, but possibly the action time of the acid should have been longer, as Bianchetti and Ramos (1982) affirm, regarding the method immersion in concentrated sulfuric acid pa (96\% purity). The authors state that it is possible to promote the immersion of the seeds for times of 5 to 20 minutes to break dormancy of the Black Wattle.

The low percentage of germination in seed without treatment proves the presence of seed dormancy. In spite of this, it is noticed that $4.5 \%$ of the seeds found adequate environmental conditions for their development, occurring thus the breakdown of dormancy by natural processes.

Figure 1 - Absolute frequency of seed germination in the different treatments $(a)(b)(c)(d)(e)$, during the four weeks of evaluation

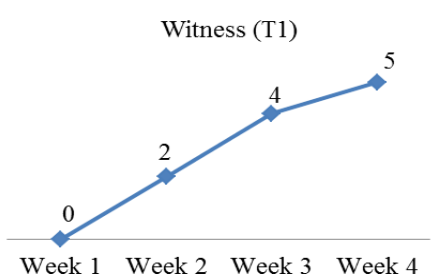

(a)
Water $90^{\circ} \mathrm{C}$ for $5^{\prime}(\mathrm{T} 2)$

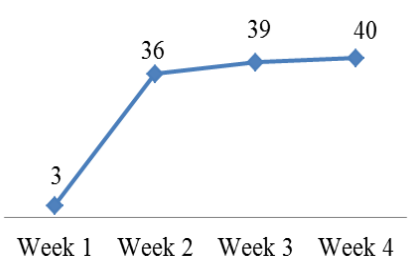

(b)
Week 1 Week 2 Week 3 Week 4

(c)
Water $90{ }^{\circ} \mathrm{C}$ for $10^{\prime}(\mathrm{T} 3)$

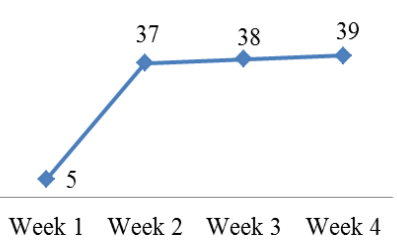

Week 1 Week 2 Week 3 Week 4 (d)

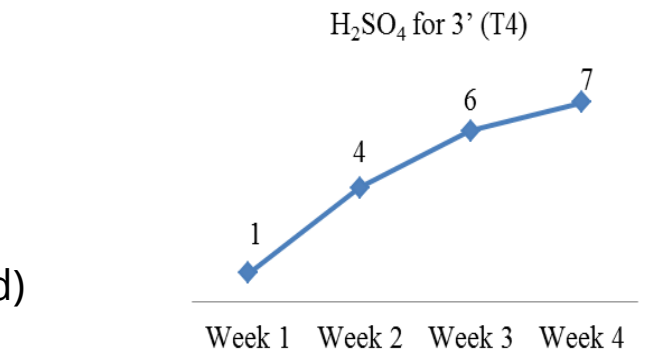

(e)

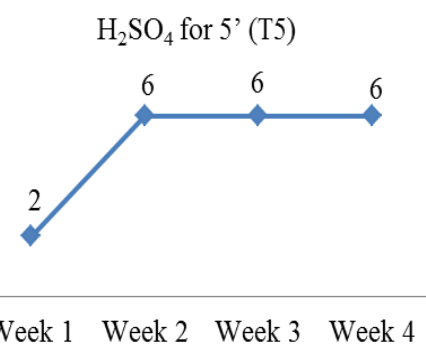


Table 1 - Averages of germination percentage in Acacia mearnsii De Wild seeds. after applying the methods of overcoming dormancy

Treatments

T1 - Witness without intervention $\%$ germination ${ }^{1}$

T2 - Immersion in water at $90^{\circ} \mathrm{C}$ for 5 ', followed by standing in water at T $9,37 c^{*}$

$\left({ }^{\circ} \mathrm{C}\right)$ ambient for $16 \mathrm{~h}$

T3 - Immersion in water at $90^{\circ} \mathrm{C}$ for 10 ', followed by standing in water at T $81,29 a^{*}$

$\left({ }^{\circ} \mathrm{C}\right)$ ambient for $16 \mathrm{~h}$

T4 - Immersion in concentrated $\mathrm{H} 2 \mathrm{SO} 4$ for 3 ', followed by washing in running water

$81,25 a^{*}$ for $10^{\prime}$

T5 - Immersion in concentrated $\mathrm{H} 2 \mathrm{SO} 4$ for 5 ', followed by washing in running water for $10^{\prime}$

$\mathrm{CV}(\%)^{2}=6,33$

*Means followed by different lowercase letters differ from each other by the $t$ test at the $5 \%$ probability level;

Percentage of germination (\%); ${ }^{2}$ Coefficient of variation (\%).

It is known that an important criterion for the cultivation of forest species is that they have a rapid and homogeneous development (KREFTA et al., 2012), so that the IVG was calculated, an important parameter to evaluate the homogeneity and speed of germination. Was observed that the best result was obtained by $T 3$, with an average germination time of 19.66 days, although $\mathrm{T} 2$ also reached a high index, which differed statistically from the best, according to Figure 2 .

For the seeds treated with immersion in concentrated sulfuric acid (T4 and T5), there was no significant difference between them for the germination percentage and IVG, but these differed from the best treatments, in both cases, only the results of the control. This showed the lowest index: 1.42 days of average time for germination.

The data presented above make it clear that it was the immersion in water at 90 ${ }^{\circ} \mathrm{C}$ for 10 minutes, followed by rest for 16 hours in water at room temperature which led to the greater speed of dormancy breaking of the seeds of this species. The association of immersion in hot water at $90{ }^{\circ} \mathrm{C}$ with water at room temperature was intended to verify if there was an increase in the germinative performance of this species. It was observed that the germination speed was higher and resulted in a significant difference with the other treatments studied. In fact, the seeds of Black Wattle have tegument dormancy due to waterproofing in the tegument, so it did not respond significantly to sowing without treatment.

For the variables evaluated at two months after sowing, it was verified that the treatment of immersion in hot water at $90^{\circ} \mathrm{C}$ for 5 minutes, followed by resting in water 
at room temperature for 16 hours (T2) was the one that demonstrated greater development of the root length of the seedlings, with $161.53 \mathrm{~mm}$ of root.

Figure 2 - Mean data of the germination speed index (IVG) of Acacia mearnsii De Wild seeds submitted to pre-germination treatments. Means followed by distinct letters differ from each other by the t test at the $5 \%$ probability level. Coefficient of variation (CV) of $4.62 \%$

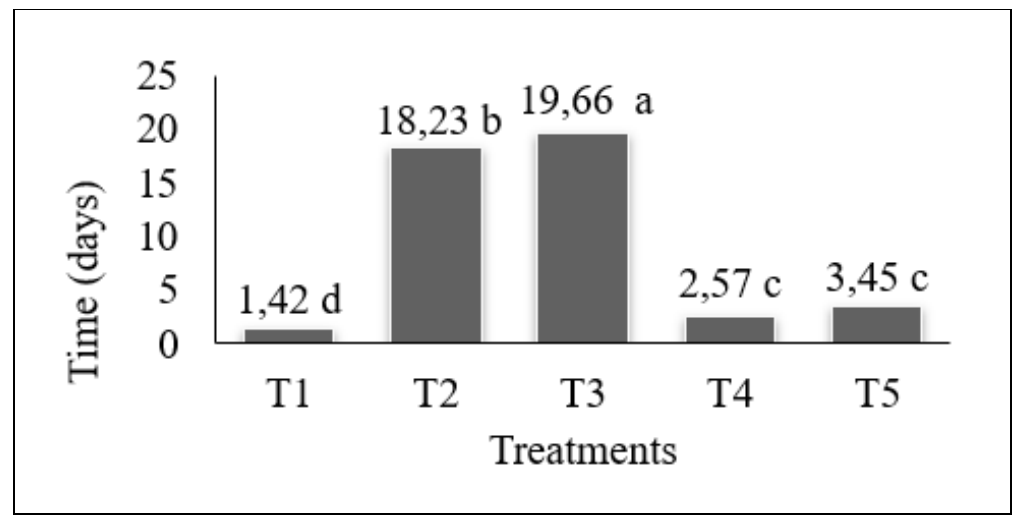

The second best response was observed with T3, with $153.25 \mathrm{~mm}$ (Table 2). This, however, did not differ statically from the witness that presented $149.17 \mathrm{~mm}$, and the witness, in turn, did not differ from the worst treatments observed: T4 and T5, with 144.64 and $146.38 \mathrm{~mm}$, respectively.Analyzing the Table 2, it can be affirmed that better results for aerial part length were also obtained with water immersion treatments at 90 ${ }^{\circ} \mathrm{C}$ for 5 and 10 minutes, followed by resting in water at room temperature for 16 hours (T2 and T3), with 49.14 and $48.31 \mathrm{~mm}$, respectively. However, there was no statistically significant difference between these treatments and the others. The highest average total length was also reached by treatment in hot water for 5 minutes: $210.67 \mathrm{~mm}$. This, reached approximately $9.0 \mathrm{~cm}$ more than the second best average (T3), according to Figure 3.

Table 2 - Results of the variables root length, aerial part length and total length analyzed under seedling nursery conditions on Black Wattle seedlings at two months after sowing

\begin{tabular}{|c|c|c|}
\hline Treatments & Root length (mm) & Length of the aerial part ( $\mathrm{mm}$ ) \\
\hline T1 & 149,17 bc & $42,83 \mathrm{a}$ \\
\hline $\mathrm{T} 2$ & $161,53 \mathrm{a}$ & 49,14 a \\
\hline T3 & $153,25 b$ & 48,31 a \\
\hline T4 & $144,64 \mathrm{c}$ & $42,02 \mathrm{a}$ \\
\hline \multirow[t]{2}{*}{ T5 } & $146,38 \mathrm{c}$ & $46,69 \mathrm{a}$ \\
\hline & $C V(\%)=8,43$ & $C V(\%)=10,01$ \\
\hline
\end{tabular}


Means followed by distinct letters in the column differ from each other by the ttest at the $5 \%$ probability level. $\mathrm{T} 1$ - Witness; $\mathrm{T} 2$ - Immersion in water at $90{ }^{\circ} \mathrm{C}$ for 5 minutes, followed by standing in water at room temperature for 16 hours; T3 Immersion in water at $90{ }^{\circ} \mathrm{C}$ for 10 minutes, followed by standing in water at room temperature for 16 hours; T4 - Immersion in $\mathrm{H}_{2} \mathrm{SO}_{4}$ for 3 minutes; T5 - Immersion in $\mathrm{H}_{2} \mathrm{SO}_{4}$ for 5 minutes.

Figure 3 - Average height of Black Wattle seedlings evaluated under different treatments of dormancy at 60 days. Means followed by distinct letters in the column differ from each other by the t-test at the $5 \%$ probability level. Coefficient of variation $(\%)=2.07$

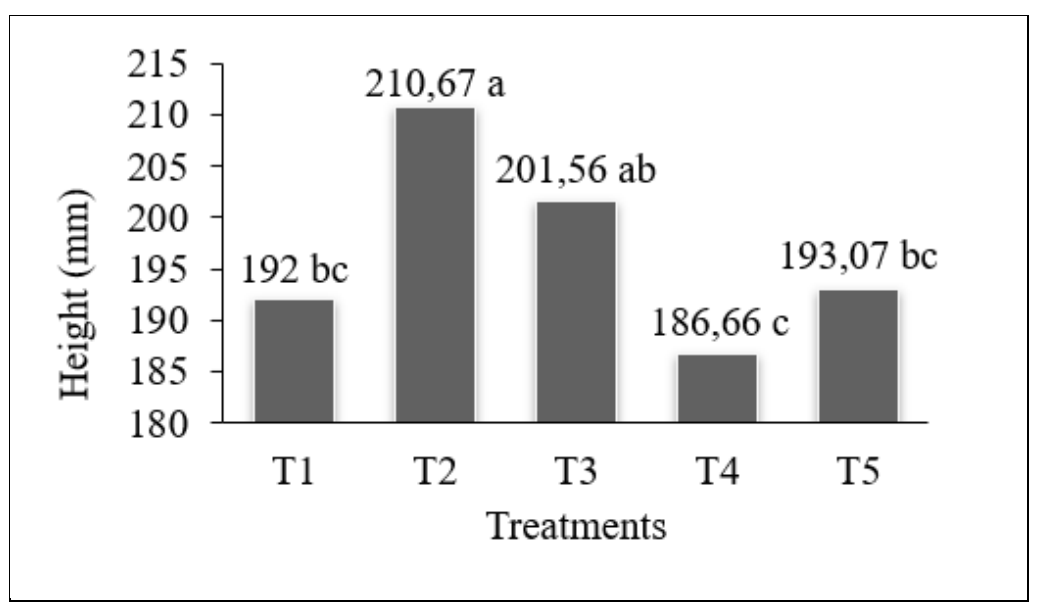

With a total length of $186.66 \mathrm{~mm}$, the treatment that favored the growth was the immersion in sulfuric acid for 3 minutes, which reinforces the study by Bianchetti and Ramos (1982) where they affirm that to promote dormancy of Black Wattle the seeds should be immersed for times of 5 to 20 minutes.

In the case of stem diameter, the control (T1) presented the best results, as shown in Table 3, with $0.98 \mathrm{~mm}$, followed by the treatment T2, with $0.91 \mathrm{~mm}$, but for this variable it was not statistically significant difference was observed among the five evaluated treatments. The worst treatment for the variable stem diameter was T4, with $0.67 \mathrm{~mm}$. 
Table 3 - Results of the variables stem diameter and green mass weight analyzed under seedling nursery conditions on Black Wattle seedlings at two months after sowing

\begin{tabular}{lcc}
\hline Treatments & Stem diameter $(\mathrm{mm})$ & Weight of the Green Mass $(\mathrm{g})$ \\
\hline T1 & $0,98 \mathrm{a}$ & $0,428 \mathrm{a}$ \\
T2 & $0,91 \mathrm{a}$ & $0,451 \mathrm{a}$ \\
T3 & $0,85 \mathrm{a}$ & $0,537 \mathrm{a}$ \\
T4 & $0,67 \mathrm{a}$ & $0,413 \mathrm{a}$ \\
T5 & $0,73 \mathrm{a}$ & $0,483 \mathrm{a}$ \\
\hline & $\mathrm{CV}(\%)=16,32$ & $\mathrm{CV}(\%)=20,06$ \\
\hline
\end{tabular}

Means followed by distinct letters in the column differ from each other by the ttest at the 5\% probability level. T1 - Witness; T2 - Immersion in water at $90{ }^{\circ} \mathrm{C}$ for 5 minutes, followed by resting in water at room temperature for 16 hours; T3 - Immersion in water at $90^{\circ} \mathrm{C}$ for 10 minutes, followed by standing in water at room temperature for 16 hours; T4 - Immersion in $\mathrm{H}_{2} \mathrm{SO}_{4}$ for 3 minutes; T5 - Immersion in $\mathrm{H}_{2} \mathrm{SO}_{4}$ for 5 minutes. As observed, for green mass weight there was also no significant difference, but T3 and T5 were the best, with 0.537 and $0.483 \mathrm{~g}$, respectively. The treatment that promoved the smallest increase in mass was $\mathrm{T} 4$, with $0.413 \mathrm{~g}$.

\section{CONCLUSIONS}

The treatment of hot water immersion at $90{ }^{\circ} \mathrm{C}$ for 5 minutes followed by rest in water at room temperature for 16 hours exceeded the rest of the methods during the evaluations in the seedling nursery, where it presented germination of $81.29 \%$ with an average time of 18.23 days.

In the evaluation of the initial development parameter the same treatment was also the one that showed more uniformity of the physical characteristics of the seedlings, with greater root length and aerial part. The treatment that least satisfied the characteristics desired for initial development was the method of immersion in $\mathrm{H}_{2} \mathrm{SO}_{4}$ for 3 minutes, which presented, for all variables, the worst means.

This study allows to conclude that for seedling nursery workers this is a good result, since immersion in hot water is a simple, low-cost, easy to handle, low-run and safe method to promote the germination of Acacia mearnsii De Wild. 


\section{REFERENCES}

ALBRECHT JMF. Estudos sobre a germinação de Mimosa scabrella Benth. e Acacia mearnsii De Wild. em função de tratamentos pré-germinativos. 1981. 63p. Dissertação (Mestrado) - Universidade Federal do Paraná, Curitiba.

ALVES MCS, MEDEIROS-FILHO S, ANDRADE-NETO M, TEÓFILO EM. Superação da dormência em sementes de Bauhinia monandra Britt. e Bauhinia ungulata L. Revista Brasileira de Sementes, 2000, 22(2): 139-144.

BARAZETTI VM, SCCOTI MSV. Quebra de dormência e tipos de substrato para avaliação da qualidade fisiológica de um lote de sementes de bracatinga (Mimosa scabrella Bentham). Unoesc \& Ciência - ACET, 2010, 1(1): 69-76.

BERTALOT MJA, NAKAGAWA J. Superação da dormência em semente de Leucaena diversifolia (Schlecht.) Bentham. Revista Brasileira de Sementes, Brasília, 1998, 20(1): 39-42.

BEWLEY JD, BLACK M. Seeds: physiology of development and germination. New York: Plenum, 2 ed., 1994.

BIANCHETTI A, RAMOS A. Quebra de dormência de sementes de canafístula (Peltophorum dubium (Spreng.) Taubert): resultados preliminares. Boletim de Pesquisa Florestal, 1981a: 77-86.

BIANCHETTI A, RAMOS A. Comparação de tratamentos para superar a dormência de sementes de Acácia Negra (Acacia mearnsii De Wild.). Boletim de Pesquisa Florestal, 1982: 101-111.

BIANCHETTI A, RAMOS A. Quebra de dormência de sementes de guapuruvu (Schizolobium parayba (Vellozo) Blake), Boletim de Pesquisa Florestal, 1981b: 69-76.

BIANCHETTI A, RAMOS A. Comparação de tratamentos para superar a dormência de sementes de bracatinga (Mimosa scabrella Bentham), Boletim de Pesquisa Florestal, 1981c: 57-67.

BRASIL. Ministério da Agricultura e Reforma Agrária. Regras para análise de sementes. Brasília: SNDA/DNDV/CLAV, 1992.

EMBRAPA. Revegetação de solos degradados. Seropédica: CNPA, 1992.

EMBRAPA. Sistema Brasileiro de Classificação de Solos, Centro Nacional de Pesquisa de Solos: Rio de Janeiro, 1999.

FRANK LB, BASEGGIO L. Superação da dormência em sementes de Desmodium incanum DC e Lathyrus nervosusi Lam. Revista Brasileira de Sementes, 1998, 20(2): 420-424. 
GARCIA J, CÍCERO SM. Superação da dormência em sementes de Brachiaria brizantha cv. Marandu. Scientia Agricola, 1992, 49(1): 9-13.

GOEDERT CO. Efeito de reagentes químicos na superação da dormência em sementes de gramíneas forrageiras. In: CONGRESSO BRASILEIRO DE SEMENTES, 4., Brasília. Resumos. Brasília, ABRATES, 1985: 231-233.

IBÁ, Indústria Brasileira de Árvores. Estatísticas da Indústria Brasileira de Árvores, Relatório 2018, 2018.

KREFTA SM, CABREIRA MAF, FACCHI SP, REFFATTI RP, PAVLAK T, BRUN EJ. Métodos para superação de dormência em acácia-negra (Acacia mearnsii De Wild.). In: CONGRESSO DE CIÊNCIA E TECNOLOGIA DA UTFPR, 2. Dois Vizinhos. Anais. Dois Vizinhos, UTFPR, 2012: 257-261.

LIMA D, GARCIA LC. Avaliação de métodos para o teste de germinação em sementes de Acacia mangium De Willd. Revista Brasileira de Sementes, 1996, 18(2): 180-185.

MAGUIRE JD. Speed of germination aid in selection and evaluation for seedling and vigour. Crop Science, 1962, 2(2):176-177.

MAYER AM, POLJAKOFF-MAYBER A. The germination of seeds. London: Pergamon Press, 1989.

NICOLOSO FT, GARLET A, ZANCHETTI F, SEBEM E. Efeitos de métodos de escarificação na superação da dormência de sementes e de substratos na germinação e no desenvolvimento da Grápia (Apuleia leiocarpa). Ciência Rural, 1997, 27(3): 419-424.

OLIVEIRA LS. Aspectos entomológicos em povoamentos homogêneos de Acacia mearnsii De Wild. 2007. 121 p. Tese (Doutorado) - Universidade Federal de Santa Maria. Santa Maria.

RECH B, GONÇALVES AB, FREITAS AJP. Determinação de tratamentos pré-germinativos para sementes de Acacia Negra (Acacia mearnsii de Wild). In: CONGRESSO FLORESTAL ESTADUAL, 4., 1980, Nova Prata. Anais. Nova Prata: Prefeitura Municipal de Nova Prata, 1980.

ROVERSI T, MATTEI VL, SILVEIRA JÚNIOR P, FALCK GL. Superação da dormência em sementes de acácia negra (Acacia Mearnsii De Wild.). Revista Brasileira de Agrociência, 2002, 8(2): 161-163.

SACCO JC. Conceituação e terminologia relacionada à dormência de sementes. Universidade Federal de Pelotas, Pelotas, 1974, 20p. (Apresentado em Curso de Iniciação à Pesquisa em Análise Sementes). 
SCHUMACHER MV, BRUN EJ, RODRIGUES LM, SANTOS EM. Retorno de nutrientes via deposição de serapilheira em povoamento de acácia-negra (Acacia mearnsii De Wild.) no estado do Rio Grande do Sul. Revista Árvore, 2003, 27(6): 791-798.

SILVA BMS, LIMA JD, DANTAS VAV, MORAES WS, SABONARO DZ. Efeito da luz no crescimento de mudas de Hymenaea parvifolia Huber. Revista Árvore, 2007, 31(6): 1019-1026.

SILVA FAZ, AZEVEDO CAV. Versão do programa computacional Assistat para o sistema operacional Windows. Revista Brasileira de Produtos Agroindustriais, 2002, 4(1): 71 78.

SILVA, FP, SILVA JG. Quebra de dormência de sementes de Acacia mangium. In: CONGRESSO FLORESTAL PANAMERICANO, 1.; CONGRESSO FLORESTAL BRASILEIRO, 7., 1993, Curitiba. Anais. São Paulo: SBS; [S.I.]: SBEF, 1993.

TORRES SB, SANTOS DSB. Superação de dormência em sementes de Acacia senegal Willd. e Parkinsonia aculeata (L.). Revista Brasileira de Sementes, 1994, 16(1): 54-57.

YAP SK, WONG SM. Seed biology of Acacia mangium, Albizia falcataria, Eucalyptus spp., Gmelina arborea, Masopsis eminiis, Pinus caribaea and Tectonia grandis. The Malaysian Forester, 1983, 6(1): 26-45. 